\title{
THE IMPACT OF PHENOLIC COMPOUNDS EXTRACTED FROM THE DATE FRUITS PRE- MATURE STAGE (JAMRY STAGE) AND THE SEEDS OF DATE (PITS OF MATURE FRUITS) ON THE FAT OXIDATION IN BEEF SAUSAGE
}

\author{
MAHMOUD F.S.A. KADOUS \\ Meat and Fish Technology Research Department, Food Technology Research Institute, \\ ARC, Giza, Egypt
}

(Manuscript received 31 December 2014)

\begin{abstract}
$\mathrm{T}$ his study was conducted to determine the antioxidant activity and total phenol compounds of date fruit (Phoenix dactylifera $L$.) in the jamry stage (Pre-mature stage where the color green fruits ) and date seeds (pits of mature fruits) and the effect of phenolic compounds extracted from date fruits in the jamry stage and date seeds compared to butylated hydroxyl toluene (BHT as synthetic antioxidant) on lipid oxidation and sensory quality attributes of beef sausage during cold storage at $0.0 \pm 0.5^{0} \mathrm{C}$ for up to 12 days. Extraction was achieved with four solvents water, water: ethanol (50:50), water: ethanol (20:80) and ethanol. The obtained results indicated that extraction by water: ethanol (20:80) had significantly the highest antioxidant activity and total phenolic compounds followed by extraction by water: ethanol (50:50) and ethanol, respectively. While the extraction by water gave the lowest antioxidant activity and total phenolic compounds. On the other hand, the antioxidant activity and total phenolic compounds of date seeds were higher than in the date in jamry stage. Addition of different concentrations of either the phenolic compound extracted and BHT (50, 75 and $100 \mathrm{mg} / \mathrm{kg}$ of meat ) to beef sausage and evaluating it's effect on the lipid oxidation of beef sausage during cold storage was studied. The obtained results indicated that all concentrations of the phenolic compounds extracted had antioxidative activity by estimating the TBA values compared to control samples. Concentration of the phenolic compounds extracted $(100 \mathrm{mg} / \mathrm{kg})$ had significantly the highest effective antioxidant and prolonged the shelf life of the beef sausage and had significantly the highest sensory evaluation scores (color, taste, odor, texture and overall acceptability) during storage period and at the end of the storage period. The results could suggest that phenolic compounds extracted can be successfully used as natural, cheap and available antioxidant to reduce or delay the oxidation processes in beef sausage.
\end{abstract}

Keywords: antioxidant activity, phenolic compounds, date seeds, date fruit, beef sausage

\section{INTRODUCTION}

The date fruits (Phoenix dactylifera L.) is considered as one of the important commercial crops in the Middle East countries. Since there are more than 
2000 varieties of dates in different parts of the world. The fruits containing a high percentage of sugars (44-88\%), fat (0.2-0.5\%), protein (2.3 to $5.6 \%$ ) and $15 \%$ type of salts, minerals and vitamins, and a high proportion of fiber 6.4 to $11.5 \%$ (Biglari, 2009). Also the date fruits contains pigments such as chlorophyll and carotenoid pigment and anthocyanins, Date contain a high content of important and necessary antioxidants for the body, it is among the wide range of phenolic compounds such as the P-coumaric, ferulic sinapic acid as essential compounds in dates. Seeds of date fruits constitutes ranged between $10 \%$ and $15 \%$ of date fruits weight. The date seeds considered as a waste of many date industries, date syrup and date confectionery. At present, seeds are used mainly for animal feeds such as cattle, sheep, and camel and poultry industries. Also seeds contain high levels of phenolics (3102-4430 mg Gallic acid /100 gm) (Ardekani, et al., 2010). Phenolic compounds of fruit seeds mainly phenolic acids and flavonids, have been shown to possess such as antioxidant, anticarcinogenic, antimicrobial, antimutagenic and antiinflamatory activities, as well as reduction of cardiovascular diseases. Antioxidants wide attention when those interested in the science of food and medical researchers for their direct impact in reducing the risk of chronic diseases such as cancer, heart disease and aging trauma. It also reduces the oxidation and crash DNA in the human body and delay the start oxidative rancidity (Peterson and Dwyer, 1998). Rancidity is responsible for taste, flavor and color changes, resulting loss of nutritional value of food and its impact on public health, due to formation toxicity compounds. Therefore require addition of antioxidants to obstruct or prevent the oxidation of biomolecules such as fat, proteins and carbohydrates and prevent the destruction of vitamins (Kaur and Kapoor, 2001), Also to prevent the formation of free radicals resulting from the oxidation of fat. The synthetic antioxidants, i.e: butylated hydroxy anisole (BHA) and butylated hydroxyl toluene (BHT) are very cost-effective given a high stability. The use of BHT and BHA in food has been decreased due to their suspected action as promoters of carcinogenesis, as well for the general consumer rejection of synthetic food additives. Several studies indicated that the use of synthetic antioxidants has begun to be restricted because of their health risks and toxicity (Farag, et al., 2006). In this respect Tariq, et al. (2000) reported the pathological changes such as wide extension at hepatocellular degeneration including cloudly swelling and vacuolar degeneration, mostly fatty degeneration produced in rats after 6-weeks administration of BHT at level $200 \mathrm{ppm}$. Therefore, the importance of replacing synthetic antioxidants with natural ingredients from oilseeds, spices and other plant materials has greatly increased. Some components isolated from fruits and vegetable has been proven in model systems, being effective as antioxidants as synthetic antioxidants (Basuny, 
2004). The aim of this study was determine antioxidant activity and total phenol content of date fruits (Phoenix dactylifera L.) in the jamry stage (Pre-mature stage where the color green fruits ) and date seeds(pits of mature fruits) and evaluation replace the use of synthetic antioxidant with the phenolic compound extracted as a healthy safe natural antioxidants from cheap and available natural sources.

\section{MATERIALS AND METHODS}

Date fruits (Phoenix dactylifera L.) class-Balah siwi in the jamry stage (Pre-mature stage where the color green fruits ) were obtained from local date farms in Giza, Egypt. The date seeds (pits of mature fruits) class-Balah siwi was directly isolate from the date fruits wastes in local market Giza, Egypt. Refrigerated beef meat was obtained from supper market at Giza, Egypt. Immediately after purchasing, samples were transported using ice box to the laboratory of Meat and Fish Technology, Food Technology Research Institute, Agriculture Research Center, Giza, Egypt. Other ingredients such as soy protein, skim milk, salt, onion, spices, garlic, starch were purchasing from local market at Giza.

\section{Samples preparation}

Date fruits in jamry stage were minced and dried under vacuum on $60^{\circ} \mathrm{C}$ for $48 \mathrm{~h}$, the date seeds (pits of mature fruits) were dried in oven at $70^{\circ} \mathrm{C}$ overnight, grinded to pass through $1 \mathrm{~mm}$ sieve using alab.mill, packaged in polyethylene bags and stored at $4^{\circ} \mathrm{C}$ until analyzed.

\section{Extraction}

The total phenols compounds (TP) of ground date of the jamry stage and date seeds were extracted using four separate solvents ( water, water : ethanol (50 :50), water : ethanol $(20: 80)$ and ethanol) where, addition ratio of solvent : dried seeds or dried minced date in jamry stage was ( $10: 1)$ and carried out using shaking incubator at room temperature for $12 \mathrm{~h}$ followed by filtration through whatman no.1 filter paper .the filtrate were centrifuged at $4000 \mathrm{rpm}$ for $10 \mathrm{~min}$.

\section{Beef sausage preparation}

Refrigerated beef meat manually cut using band saw and minced through $24 \mathrm{~mm}$ and mixed with other ingredients (minced meat 60\%, fat $15.0 \%$, water 7.0 $\%$, soy protein $10 \%$, starch $4.0 \%$, sodium pyrophosphate $0.3 \%$, salt $2.0 \%$, garlic $0.3 \%$, skim milk $0.4 \%$ and spice $1.0 \%$ ) then divided into four groups were mixed by gloved hand with $0.0,50,75$ and $100(\mathrm{mg} / \mathrm{kg}$ of meat) from the highest antioxidant efficiency of extracts and butylated hydroxyl toluene ( BHT ) / meat weight. Each group of four groups was then stuffed into casing sausage by the filling machine then packaged it in foam dishes then wrapping by polyethylene bags and stored at $0.0 \pm 0.5^{\circ} \mathrm{C}$ up to 12 days until chemical and sensory analysis. 


\section{Analytical methods}

Proximate analysis including moisture, total protein, fat ( ether extract) and ash were carried out according to the methods of (AOAC, 2005) and Carbohydrates was calculated by difference. Thiobarbituric acid (T.B.A) value was determined according (pearson, 1970).

Measurement of the total phenolic compounds.

Total phenolics were determined colorimetrically using Folin-Ciocalteu reagent as described by (Velioglu, et al.,1998) with slight modifications. The prepared extract $(200 \mu \mathrm{L}$ ) was mixed with $1.5 \mathrm{~mL}$ of Folin-Ciocaltue reagent (previously diluted 10 fold with distilled water) and allowed to stand at $200^{\circ} \mathrm{C}$ for $5 \mathrm{~min}$. A $1.5 \mathrm{~mL}$ sodium bicarbonate solution $(60 \mathrm{~g} / \mathrm{L})$ was added to the mixture. After $90 \mathrm{~min}$ at $22^{\circ} \mathrm{C}$, the absorbance was measured at $725 \mathrm{~nm}$ using a UV spectrophotometer (Pharmacia Biotech). The total phenolics were quantified by the calibration curve obtained from measuring the absorbance of a known concentration of gallic acid (GA) standard (20$150 \mathrm{mg} / \mathrm{Lit}$ ). The concentrations were expressed as equivalent milligrams of gallic acid (GA) per $100 \mathrm{~g}$ dry weight.

\section{DPPH radical scavenging activity}

Scavenging Radical activity of extracts (of ground date of the jamry stage and date seeds were extracted using four separated solvents) against stable DPPH• (2-diphenyl-2- picrylhydrazyl hydrate). This method was determined spectrophotometrically. When DPPH• reacts with an antioxidant compound, which can donate hydrogen, it is reduced. The changes in color (from deep-violet to light-yellow) were measured at $517 \mathrm{~nm}$ on a UV-visible light spectrophotometer (UV-1601). The antioxidant activity of the extract was expressed as an IC50 value defined as the concentration (in $\mathrm{mg} / \mathrm{l}$ ) of the extract that inhibited the formation of DPPH radicals by 50\%( Djeridane, et al, 2006).

\section{Sensory evaluation}

Sensory evaluation was determined according to (Suderman, et al. 1981). Samples were prepared by frying in plant oil for (5-10 $\mathrm{min}$ ) and subjected to member $s$ trained sensory panel to (more than 10 ) find out the formulas that have more palatability by evaluating color, odor, taste, texture and overall acceptability .

\section{Statistical analysis.}

Analysis of variance. Duncan's multiple range tests at $(P \leq 0.05)$ level was used to compare between means( where, $a, b, c, d, e$.....etc means that there is significant differences between the samples by Statistical analysis and a was the best followed by b, c, d ,e....etc). The analysis was carried out using the PRO ANOVA procedure of Statistical Analysis System (SAS Institute, 1996). 


\section{RESULTS AND DISCUSSION}

To compare the effect of the extraction methods on antioxidants activities and total phenolic contents in date seeds and date in jamry stage ( of Balah Siwi), four different solvents were used (figure 1 and 2 ). All the extracts contained considerable phenolic content from the equivalent of $750 \mathrm{mg} \mathrm{GA} / 100 \mathrm{~g}$ dry weight of date in jamry stage to $3498 \mathrm{mg} \mathrm{GA} / 100 \mathrm{~g}$ dry weight of date seeds (figure 1). All the extracts had considerable antioxidant activities from the equivalent of $32.11 \%$ in date in jamry stage to $71.64 \%$ in date seeds (figure 2). These results indicated that presence the direct relationship between the total phenolic content and antioxidant activity, whereas the antioxidant activity of extracts increased with increasing of the total phenol content of these extracts. Significant differences ( $p \geq$ 0.05 ) existed among different solvents used, with some exception, Hence extraction by water: ethanol (20:80) had significantly the highest antioxidant activity and total phenolic compounds followed by extraction by water : ethanol (50:50) and ethanol ,respectively. While the extraction by water gave the lowest antioxidant activity and total phenolic compounds. On the other hand, the antioxidant activity and total phenolic contents of date seeds were higher than in the date in jamry stage. These results agreement with the obtained results by other researchers, hence (Mohamed and Al-okbi,2005) reported that antioxidant activities of different extracts of edible portion of date fruit ranged from $9.28 \%$ to $75.96 \%$ and the total phenolic content was found to be $1416 \mathrm{mg} \mathrm{GA} / 100 \mathrm{~g}$ dry weight. (Khanavi, et al, 2009) indicated that antioxidant activities of different extracts of date fruits ( Khenizi variety ) ranged from $5.45 \%$ to $56.61 \%$ and the total phenolic content ranged from 102.72 to $276 \mathrm{mg} \mathrm{GA}$ / $100 \mathrm{~g}$ dry weight . ( Shams Ardekani, et al, 2010) reported that total phenolic content and antioxidants activity of different extracts of 14 varieties of date seeds ranged from $1260 \mathrm{mg} \mathrm{GA} / 100 \mathrm{~g}$ dry weight and $13.13 \mathrm{~m} \mathrm{~mol}$ of $\mathrm{Fe}^{11} / 100 \mathrm{~g}$ dry weight to 3541 $\mathrm{mg} \mathrm{GA} / 100 \mathrm{~g}$ dry weight and $37.42 \mathrm{~m} \mathrm{~mol}$ of $\mathrm{Fe}^{11} / 100 \mathrm{~g}$ dry weight, respectively. Also their total phenolic content was reported as 3250 and $4370 \mathrm{mg} \mathrm{GA} / 100 \mathrm{~g}$ dry weight (Biglari, et al, 2008). This variation may be related to different methods of extraction. The phenol compounds are considered as an important group of natural antioxidants with possible beneficial effects on human health. They can participate in protection against the harmful action of reactive oxygen species, mainly oxygen free radicals. (Meyers, et al, 2003) reported that the phenols compounds are known also to passes antioxidant activity due to its stability to reduce free radical stability via electron or hydrogen- donating. Also the antioxidant activity of phenolic compounds is principaly based on the properties of hydroxyl group and the structural relationship between different parts of their chemical structure. 


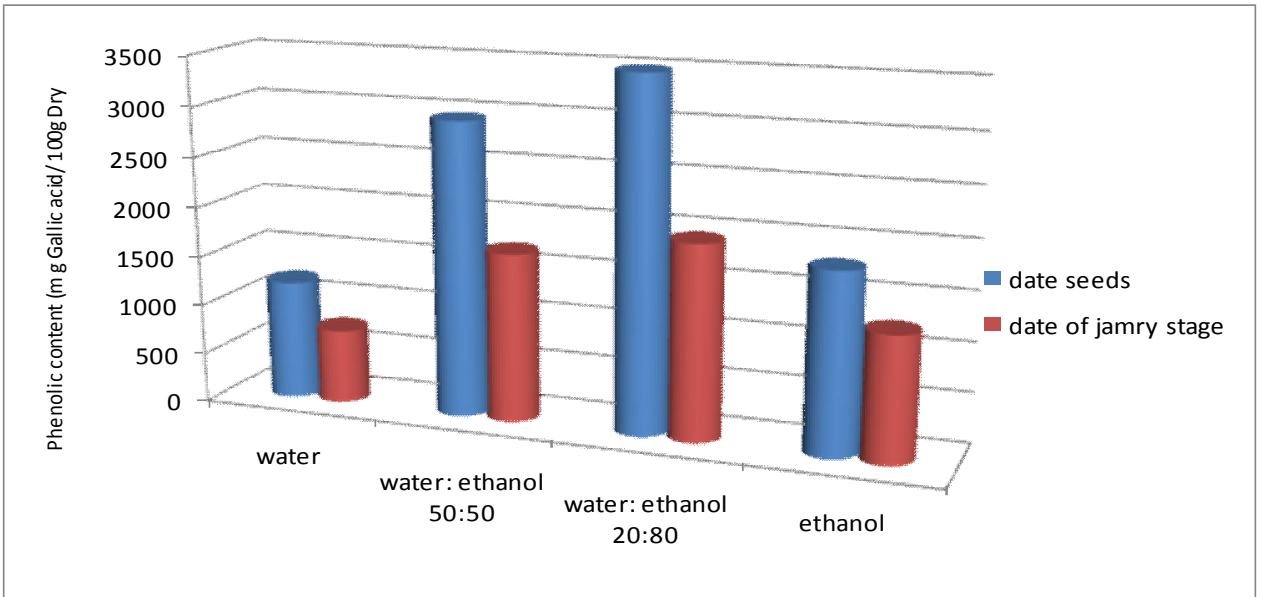

Figure 1. Phenolic content (mg Gallic acid/ $100 \mathrm{~g}$ dry weight) of date seeds and date in jamry stage with four extract solvents. Data mean \pm SE. Each sample was analyzed triplicate times.

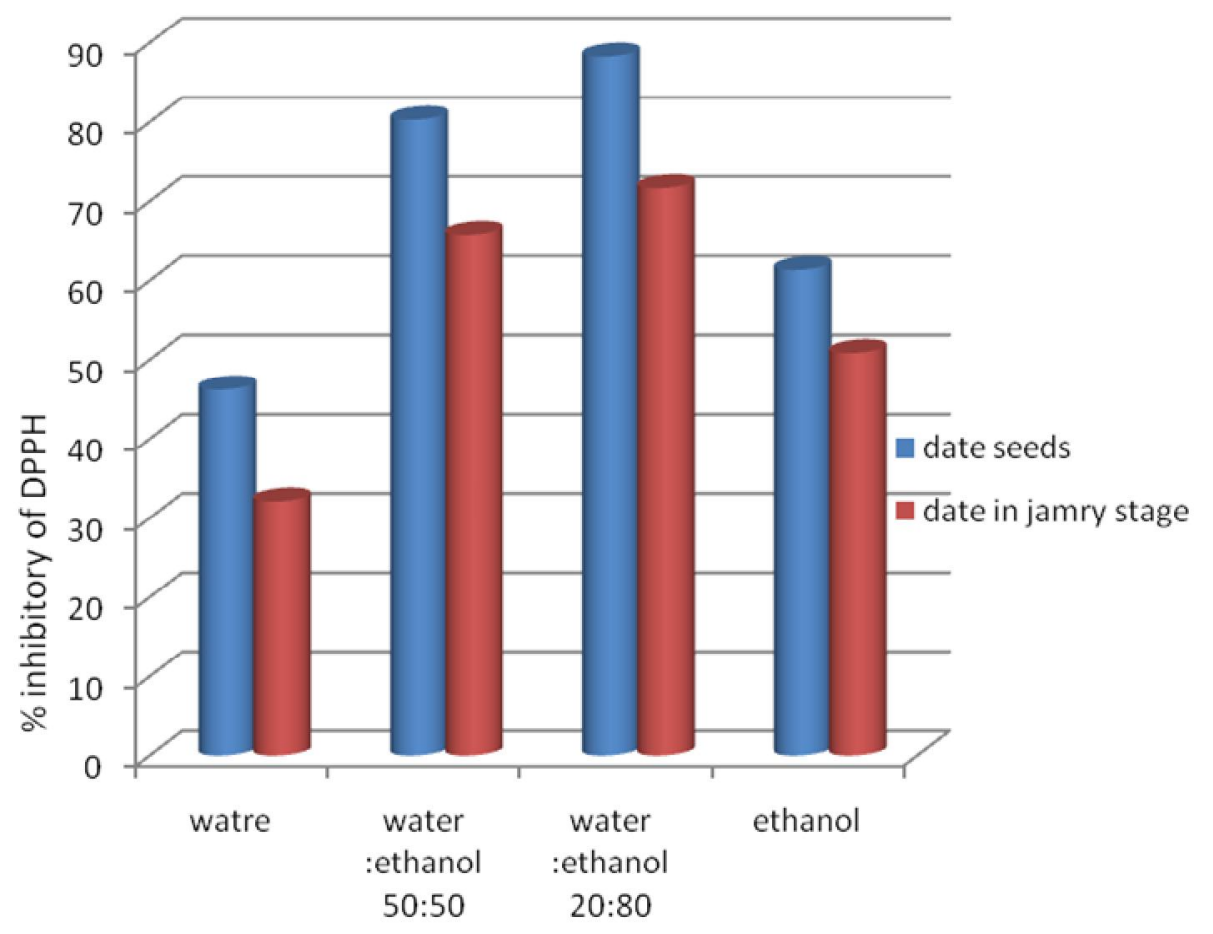

Figure 2. Antioxidant activity (DPPH \% of Inhibitory) of date seeds and date in jamry stage with four extract solvents. Data mean \pm SE. Each sample was analyzed triplicate times.

\section{Chemical composition of meat sausage.}

Table (1) showed that chemical composition of beef sausage. This results pointed that the moisture, protein, fat, ash and carbohydrate content of meat sausage were $58.93,16.85,18.1,2.75$ and $3.40 \%$, respectively. The obtained 
results also indicated that the beef sausage contain relatively high fat content which causes quality deterioration in meat and its cooked products where existance direct relationship between fat content and the speed of rancidity and deterioration of sensory quality attributes of meat products.

Table 1. Chemical composition of beef sausage

\begin{tabular}{|c|c|}
\hline component & $\mathrm{g} / 100 \mathrm{~g}$ (wet weight) \\
\hline Moisture & 58.93 \\
\hline Protein & 16.85 \\
\hline Fat & 18.10 \\
\hline Ash & 2.72 \\
\hline Carbohydrate & 3.40 \\
\hline
\end{tabular}

\section{T.B.A value of beef sausage .}

Meat products turn to become rancid and brown more rapidly, due to pigments and lipid oxidation. An oxidative reaction in muscles foods leads to degradation of lipid and protein, resulting in deterioration of taste, aroma, texture and nutritive value and is considered as one of the major problems in the development of new convenient meat products. Table ( 2 ) shows the effect of different concentrations of the phenolic compounds extracted and BHT (50, 75 and $100 \mathrm{mg} / \mathrm{kg}$ of meat) on the changes of T.B.A values of beef sausage stored for period 12 day at $0.0{ }^{\circ} \mathrm{C}$. The obtained results indicated that mixing minced meat with various levels of phenolic compounds extracted (50,75 and $100 \mathrm{mg} / \mathrm{kg}$ of meat) caused significant $(p \geq 0.05)$ reduction of T.B.A values compared to control samples at zero time or any time of storage period. Generally T.B.A values increased gradually and significantly $(p \geq 0.05)$ during storage period. However, control samples had significantly the highest T.B.A value ( $2.1 \mathrm{mg}$ malondialdehyde $\mathrm{kg}-1$ meat $)$ at the end of the storage period. The highest T.B.A value of control samples might be due to an interaction between the natural substances ( for example iron ion ) from the tissue during storage. This may be due to antioxidant activity of phenolic compounds extracted which reduce lipid oxidation of beef sausage but to varying degrees depending on the concentration, and effectiveness of antioxidants increased with increasing the concentration. There were no significant differences between the T.B.A values for the different concentration of phenolic compounds extracted ( 50,75 and $100 \mathrm{mg} / \mathrm{kg}$ of meat) and its value to chemical antioxidant (BHT), while observed rapid increase in T.B.A values of the control samples. 
Table 2. Effect of phenolic compounds extracted and BHT on TBA values (mg malondialdehyde $\mathrm{kg}-1$ meat) of beef sausage during storage at $0.0^{\circ} \mathrm{C}$.

\begin{tabular}{|c|c|c|c|c|c|c|c|c|}
\hline \multirow{2}{*}{$\begin{array}{c}\text { Storage } \\
\text { periods } \\
\text { (day) }\end{array}$} & \multirow[t]{2}{*}{ control } & \multicolumn{3}{|c|}{$\begin{array}{l}\text { phenolic compound extracted } \\
\qquad \mathrm{mg} / \mathrm{kg} \text { of meat }\end{array}$} & \multicolumn{3}{|c|}{$\begin{array}{c}\text { BHT } \\
\mathrm{mg} / \mathrm{kg} \text { of meat }\end{array}$} & \multirow[t]{2}{*}{ LSD } \\
\hline & & 50 & 75 & 100 & 50 & 75 & 100 & \\
\hline 0 & $0.112 a \pm 0.02$ & $0.109 a \pm 0.02$ & $0.106 a \pm 0.01$ & $0.103 a \pm 0.01$ & $0.109 a \pm 0.02$ & $0.106 a \pm 0.01$ & $0.104 a \pm 0.01$ & 0.0276 \\
\hline 3 & $0.766 c \pm 0.08$ & $0.300 b c \pm 0.1$ & $0.220 b \pm 0.1$ & $0.13 a \pm 0.01$ & $0.333 b c \pm 0.05$ & $0.25 b \pm 0.09$ & $0.14 a \pm 0.03$ & 0.1433 \\
\hline 6 & $1.113 c \pm 0.14$ & $0.52 b c \pm 0.09$ & $0.46 b \pm 0.09$ & $0.3 a \pm 0.09$ & $0.51 b c \pm 0.1$ & $0.50 \mathrm{~b} \pm 0.08$ & $0.32 \mathrm{a} \pm 0.09$ & 0.1684 \\
\hline 9 & $1.5 c \pm 0.2$ & $0.78 b c \pm 0.09$ & $0.6 a b \pm 0.08$ & $0.54 a \pm 0.1$ & $0.8 b c \pm 0.13$ & $0.65 a b \pm 0.01$ & $0.55 a \pm 0.09$ & 0.2027 \\
\hline 12 & $2.1 c \pm 0.4$ & $1.38 c \pm 0.13$ & $1.23 b c \pm 0.12$ & $0.8 \mathrm{a} \pm 0.14$ & $1.5 \mathrm{c} \pm 0.18$ & $1.28 \mathrm{bc} \pm 0.16$ & $0.825 a \pm 0.07$ & 0.3416 \\
\hline
\end{tabular}

Values are means for $3 \pm S D$. There is significant difference between two means have the letter $(P>0.05)$. 
According to Egyptian Organization of Standardization (2005) of beef sausage it should not be containing T.B.A. values more than $0.9 \mathrm{mg}$ malonaldehyde / $\mathrm{kg}$ (w.w). From data founded in table (2), it could be noticed that control samples were spoiled after storage for 6 days at $0.0^{\circ} \mathrm{C}$, where recorded $1.11 \mathrm{mg}$ malonaldehyde $/ \mathrm{kg}$. while, treated samples (of either plenolic compounds extracted or BHT) at level 50 and $75 \mathrm{mg} / \mathrm{kg}$ of meat were spoiled after 12days, where recorded 1.38,1.23,1.5 and $1.28 \mathrm{mg}$ malonaldehyde / $\mathrm{kg}$. respectively. On the other hand, it is clearly that the sample treated with level $100 \mathrm{mg} / \mathrm{kg}$ of meat this level of T.B.A values did not exceeded of concentration $100 \mathrm{mg} / \mathrm{kg}$ of meat (of either plenolic compounds extracted or $\mathrm{BHT}$ ), where was below the permitted, it was recorded 0.8 and 0.825 mg malonaldehyde $/ \mathrm{kg}$ after stored 12 days at $0.0^{\circ} \mathrm{C}$, respectively. The results of TBA value (which considerable indicator for lipid oxidation) suggest that the phenolic compounds extracted can be successfully used as natural and cheap antioxidants. That the phospholipids in muscle membrane provide an ideal substrate for lipid oxidation, iron bound to negatively charged phospholipids promotes lipid oxidation , resulting in generation of warmed- over flavor. Basuony (2004) reported that mixing oil with various levels of grape seed phenolic compounds caused significant decrease of the formation of secondary products during frying process.

\section{Sensory evaluation}

Table (3) showed that sensory characteristics of cooked beef sausage as affected by adding different concentrations of phenolic compounds extracted and $\mathrm{BHT}$. It could be noticed that treated samples with different concentrations of phenolic compounds extracted ( 50, 75 and $100 \mathrm{mg} / \mathrm{kg}$ of meat) had relatively high scores of color, taste, odor, texture and overall acceptability when compared to control sample at zero time after manufacturing . Generally sensory evaluation scores (color, taste, odor, texture and overall acceptability) decreased gradually and significantly $(p \geq 0.05)$ during storage period. But it could be noticed that treated samples with different concentrations of phenolic compound extracted ( 50,75 and $100 \mathrm{mg} / \mathrm{kg}$ of meat) had significantly the highest sensory evaluation scores (color, taste, odor, texture and overall acceptability) during and at the end of storage periods when compared with control sample. This might be due to the phenolic compounds extracted which had antioxidants properties reduce the oxidative processes in meat Products and thus reduce incidence of changes in sensory properties. The results could suggest that phenolic compounds extracted can be successfully used as natural antioxidants to reduce or delay the oxidation processes of beef sausage, this may be due to the antioxidant compound delay the start of oxidative rancidity responsible for taste, flavor and color changes, resulting loss of nutritional value of food and its impact on 
public health, the formation toxicity compounds therefore requires the addition of antioxidants to obstruct or prevent the oxidation of biomolecules as fat, proteins and carbohydrates and prevent the destruction of vitamins (Madsen and Bertelsen, 1995). No significant differences were observed in sensory evaluation (color, taste, odor, texture and overall acceptability) between treated samples with concentrations of phenolic compounds extracted ( 50 and $75 \mathrm{mg} / \mathrm{kg}$ of meat ) and treated samples with concentrations of BHT (50 and $75 \mathrm{mg} / \mathrm{kg}$ of meat), respectively. On the other hand samples treated with concentration of phenolic compounds extracted (100 $\mathrm{mg} / \mathrm{kg}$ of meat) had significantly ( $\mathrm{p} \geq 0.05$ ) the highest scores of sensory evaluation color, taste, odor, texture and overall acceptability) during storage periods when compared with samples treated with the same concentration of BHT $(100 \mathrm{mg} / \mathrm{kg}$ of meat).

\section{CONCULSION}

The obtained results from the current study suggested that dates in jamry stage (Pre-mature stage where the green color fruits) and date seeds (pits of mature fruits) had significantly the highest antioxidant activity and total phenolic compounds extracted by (water: ethanol, 20: 80 ) followed by extraction by water: ethanol (50:50) and ethanol, respectively. While the extraction by water only had the lowest antioxidant activity and total phenolic compounds. Addition level $(100 \mathrm{mg} / \mathrm{kg}$ of meat) of the phenolic compound extracted had significantly the highest effective antioxidant by estimating the TBA values and prolonged the shelf life of the beef sausage product and had significantly the highest sensory evaluation scores (color, taste, odor, texture and overall acceptability) during and at the end of storage periods. The results could suggest that phenolic compounds extracted can be successfully used as natural, cheap and available antioxidants to reduce or delay the oxidation processes of beef sausage. 
Table 3. Effect of phenolic compounds extracted and BHT on sensory evaluation of meat sausage during storage at $0.0^{\circ} \mathrm{C}$

\begin{tabular}{|c|c|c|c|c|c|c|c|c|c|}
\hline \multirow{2}{*}{ 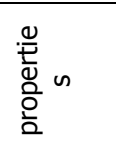 } & \multirow{2}{*}{$\begin{array}{c}\text { Storage } \\
\text { periods } \\
\text { (day) }\end{array}$} & \multirow[t]{2}{*}{ control } & \multicolumn{3}{|c|}{$\begin{array}{l}\text { phenolic compounds extracted } \\
\mathrm{mg} / \mathrm{kg} \text { of meat }\end{array}$} & \multicolumn{3}{|c|}{$\begin{array}{c}\text { BHT } \\
\mathrm{mg} / \mathrm{kg} \text { of meat }\end{array}$} & \multirow[t]{2}{*}{ LSD } \\
\hline & & & 50 & 75 & 100 & 50 & 75 & 100 & \\
\hline \multirow{5}{*}{ 흥 } & 0 & $8.47 a \pm 0.02$ & $8.49 a \pm 0.03$ & $8.51 \mathrm{a} \pm 0.05$ & $8.55 a \pm 0.02$ & $8.49 a \pm 0.02$ & $8.50 a \pm 0.05$ & $8.53 a \pm 0.03$ & 0.0838 \\
\hline & 3 & $6.18 c \pm 0.17$ & $7.56 \mathrm{~b} \pm 0.05$ & $8.28 a \pm 0.15$ & $8.4 a \pm 0.05$ & $7.51 \mathrm{~b} \pm 0.15$ & $8.26 a \pm 0.15$ & $8.35 a \pm 0.04$ & 0.2022 \\
\hline & 6 & $5.3 d \pm 0.19$ & $6.1 c \pm 0.05$ & $7.54 b \pm 0.13$ & $8.25 a \pm 0.61$ & $6.03 c \pm 0.05$ & $7.3 b \pm 0.15$ & $7.8 a b \pm 0.18$ & 0.4651 \\
\hline & 9 & $5.08 \mathrm{e} \pm 0.08$ & $5.7 d \pm 0.15$ & $7.13 b c \pm 0.03$ & $7.43 a \pm 0.07$ & $5.6 \mathrm{~d} \pm 0.15$ & $7.05 b c \pm 0.05$ & $7.28 a b \pm 0.12$ & 0.1851 \\
\hline & 12 & $4.8 \mathrm{e} \pm 0.23$ & $5.22 c \pm 0.09$ & $6.12 b c \pm 0.12$ & $6.86 a \pm 0.2$ & $5.15 c \pm 0.06$ & $6.03 b c \pm 0.15$ & $6.66 \mathrm{~b} \pm 0.15$ & 0.2771 \\
\hline \multirow{5}{*}{ 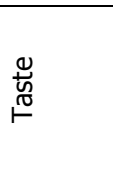 } & 0 & $7.99 a \pm 0.04$ & $8.03 a \pm 0.04$ & $8.03 a \pm 0.02$ & $8.04 a \pm 0.01$ & $8.03 a \pm 0.4$ & $8.03 a \pm 0.03$ & $8.04 \pm 0.02$ & 0.3001 \\
\hline & 3 & $5.55 \mathrm{~d} \pm 0.2$ & $7.00 c \pm 0.05$ & $7.78 \mathrm{~b} \pm 0.19$ & $8.01 a \pm 0.12$ & $6.88 c \pm 0.08$ & $7.68 \mathrm{~b} \pm 0.11$ & $7.85 a b \pm 0.1$ & 0.2300 \\
\hline & 6 & - & $6.20 c \pm 0.13$ & $7.03 b \pm 0.12$ & $7.25 a \pm 0.22$ & $6.15 c \pm 0.13$ & $6.82 \mathrm{~b} \pm 0.50$ & $7.2 \mathrm{ab} \pm 0.05$ & 0.4291 \\
\hline & 9 & - & $5.35 c \pm 0.1$ & $6.75 b \pm 0.1$ & $6.92 a \pm 0.07$ & $5.30 c \pm 0.05$ & $6.65 b \pm 0.05$ & $6.9 a \pm 0.05$ & 0.1467 \\
\hline & 12 & - & - & $6.2 \mathrm{~b} \pm .16$ & $6.58 a \pm 0.05$ & - & $6.08 \mathrm{~b} \pm .23$ & $6.53 a \pm .05$ & 0.2977 \\
\hline \multirow{5}{*}{$\frac{0}{0}$} & 0 & $7.97 a \pm 0.04$ & $8.041 a \pm 0.4$ & $8.04 a \pm 0.04$ & $8.15 a \pm 0.03$ & $8.01 a \pm 0.02$ & $8.04 a \pm 0.01$ & $8.04 a \pm 0.02$ & 02075 \\
\hline & 3 & $5.45 d \pm 0.2$ & $7.01 c \pm 0.04$ & $7.6 \mathrm{~b} \pm 0.1$ & $7.8 a \pm 0.05$ & $6.9 c \pm 0.06$ & $7.5 b \pm 0.1$ & $7.65 a b \pm 0.05$ & 0.1771 \\
\hline & 6 & - & $6.17 c \pm 0.10$ & $6.78 \mathrm{ab} \pm 0.08$ & $7.02 a \pm 0.08$ & $6.12 c \pm 0.10$ & $6.56 \mathrm{~b} \pm 0.5$ & $6.83 a b \pm 0.15$ & 0.3977 \\
\hline & 9 & - & $5.30 c \pm 0.13$ & $6.5 b \pm 0.1$ & $6.85 a \pm 0.05$ & $5.25 c \pm 0.13$ & $6.28 b \pm 0.1$ & $6.73 a b \pm 0.5$ & 0.1803 \\
\hline & 12 & - & - & $5.7 \mathrm{~b} \pm .017$ & $6.22 a \pm .03$ & - & $5.58 b \pm .22$ & $6.11 a b \pm .05$ & 02225 \\
\hline \multirow{5}{*}{ 竞 } & 0 & $7.72 c \pm 0.03$ & $7.83 b \pm 0.03$ & $7.88 a b \pm 0.02$ & $7.98 a \pm 0.15$ & $7.83 b \pm 0.03$ & $7.84 b \pm 0.05$ & $7.89 a b \pm 0.15$ & 0.1206 \\
\hline & 3 & $6.71 \mathrm{~d} \pm 0.1$ & $7.02 c \pm 0.02$ & $7.32 \mathrm{~b} \pm 0.16$ & $7.71 \mathrm{a} \pm 0.06$ & $6.97 c \pm 0.03$ & $7.29 b \pm 0.2$ & $7.68 a \pm 0.08$ & 02161 \\
\hline & 6 & $5.95 \mathrm{~d} \pm 0.1$ & $6.11 c \pm 0.13$ & $7.28 b \pm 0.03$ & $7.60 \mathrm{a} \pm 0.05$ & $6.05 \mathrm{~cd} \pm 0.15$ & $7.21 \mathrm{~b} \pm .04$ & $7.50 \mathrm{ab} \pm 0.01$ & 0.1523 \\
\hline & 9 & $5.15 \mathrm{e} \pm 0.1$ & $5.46 \mathrm{~d} \pm 0.09$ & $6.12 c \pm 0.13$ & $7.18 \mathrm{a} \pm 0.06$ & $5.41 \mathrm{~d} \pm 0.09$ & $6.08 c \pm 0.1$ & $7.0 \mathrm{~b} \pm 0.1$ & 0.1692 \\
\hline & 12 & - & - & $5.93 c \pm 0.11$ & $6.8 \mathrm{a} \pm 0.1$ & - & $5.85 \mathrm{c} \pm 0.05$ & $6.6 b \pm 0.1$ & 0.1718 \\
\hline \multirow{5}{*}{ 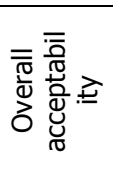 } & 0 & $8.04 a \pm 0.04$ & $8.1 a \pm 0.05$ & $8.12 a \pm 0.32$ & $8.18 a \pm 0.04$ & $8.09 a \pm 0.22$ & $8.1 a \pm 0.3$ & $8.13 a \pm 0.3$ & 0.3846 \\
\hline & 3 & $5.97 c \pm 0.19$ & $7.09 b \pm 0.36$ & $7.81 \mathrm{~b} \pm 0.4$ & $7.98 a \pm 0.08$ & $7.07 \mathrm{~b} \pm 0.3$ & $7.77 \mathrm{~b} \pm .27$ & $7.88 \mathrm{ab} \pm .3$ & 0.5124 \\
\hline & 6 & - & $6.12 c \pm 0.3$ & $7.16 \mathrm{~b} \pm 0.29$ & $7.73 a \pm 0.13$ & $6.09 c \pm 0.44$ & $6.97 \mathrm{~b} \pm 0.33$ & $7.33 a b \pm 0.33$ & 0.5638 \\
\hline & 9 & - & $5.45 c \pm 0.29$ & $6.63 \mathrm{~b} \pm 0.29$ & $7.1 \mathrm{a} \pm 0.02$ & $5.39 c \pm 0.28$ & $6.52 b \pm 0.32$ & $6.98 \mathrm{~b} \pm 0.32$ & 0.4894 \\
\hline & 12 & - & - & $5.99 c \pm 0.3$ & $6.64 a \pm 0.23$ & - & $5.43 c \pm 0.28$ & $6.48 \mathrm{~b} \pm 0.32$ & 0.5386 \\
\hline
\end{tabular}

Values are means for $3 \pm S D$. There is significant difference between two means have the letter $(P>0.05)$.

= spoiled sample (expired) 


\section{REFERENCES}

1. Ardekani, M. R., Khanavi, M., Hajimahmoodi, M., Jahangiri, M. and Hadjiakhoondi, A. 2010. Comparison of antioxidant activity and total phenol contents of some date seed varieties from Iran. Iranian Journal of Pharmaceutical Research 9: 141-146.

2. O. A. C. 2005. Official methods of analysis of the Association of official Analytical Chemists, 178th Edn (edited by W. Horwitz Washington, D.C.,U.S.A.

3. Basuony, A. M. 2004. Influence of grape seed phenolic compounds on thermal stability of frying oils. Egypt. Journal Food Science 32: 65-78.

4. Biglari,F.,Abbas,F.M., ALKarkhi, M. and Easa, A. M. 2008. Antioxidant activity and phenolic content of various date palm (Phoenix dactylifera) fruits from Iran. J.Food Chem,107: 1636-1641.

5. Biglari, F. 2009. Assessment of antioxidant potential of date (Phoenix dactylifera) fruits from Iran, effect of cold storage and addition to minced chicken meat. Msc. thesis ,University Sains Malysia. Malysia, pp.175.

6. Djeridane A., Yousfi M., Nadjemi B., Maamrim S., Djireb F. And Stocker P. 2006. Phenolic extracts from various Algerian plants as strong inhibitors of porcine liver carboxylesterase. Journal of Enzyme Inhibition and Medicinal Chemistry, 21: 719726.

7. Egyptian Organization standardization E. O. S. 2005. Frozen sausag. E.S: 19722005, ICS : 67.120.10.

8. Farag, R. S., Mohamoud, E. A., Basuny, A. M. and Ali, R. 2006. Influence of crude olive leaf on rat liver and kidney function. International Journal of Food Technology, 41: 1-10.

9. Kaur, C. and Kapoor , H.C. 2001. Antioxidants in fruit and vegetables- The millennium' health. International J. Food Sci. Tech., 36: 703-725.

10. Khanavi, M., Saghari, Z., Mohammadirad, A., Khademi, R., Hadjiakhoondi, A. and Abdollahi, M. (2009). Comparison of antioxidant activity and total phenols of some date varieties. . Daru 17: 104-107.

11. Madsen,H.L. and Bertelsen ,G. 1995. Spices as antioxidant, Food sci. Tech., 7: 271-277.

12. Mohamed, D.A. and Al-Okbi, S.Y. 2005. In vitro evaluation of antioxidant activity of different extracts of Phoenix dactylifera L. fruits as functional foods. Deut. Lebensm. Rundsch, 101: 305-308. 
13. Meyers, K. J., Watkins, C. B., Pritts, M. P. and Liu, R. H. 2003. Antioxidant and antiproliferative activities of strawberries. Journal Agricultural Food Chemistry, 51: 6887-6892.

14. Pearson, D. 1970. The chemical analysis of food. National college of reading. Wegbridge, Surry. J. and Chirchill, A.

15. Peterson, J. and Dwyer, J. 1998). Flavonoids: Dietary occurrence and biochemical activity. Nutrition Research, 18: 1995-2018.

16. SAS Institute Inc. 1996. SAS/STAT1 User's Guide, Version 8, SAS Institute Inc, Cary, NC.

17. Shams Ardekani, M.R., Khanavi, M., Hajimahmoodi, M. , Jahangiri, M. and Hadjiakhoondi, A. 2010. Comparison of Antioxidant Activity and Total

18. Phenol Contents of some Date Seed. Iranian Journal of Pharmaceutical Research, 9 (2): 141-146.

19. Suderman, D. R. , Wiker, J. and Cunningham, F. E. 1981. Factors affecting adhesion of coating to poultry skin. effects of various protein and gum sources in the coating composition. Food Sci., 46: 1010-1011.

20. Tariq, N., Jenkins, D. J. A., Vidgen, E., Fleshner, N., Kenndall, C. W. C. and Story, J. A. 2000. Effect of soluble and insoluble fiber diets on serum prostate specific antigen in men. The Journal of Urology, 163: 114-118.

21. Velioglu, Y. S., Mazza, G., Goo, L. and Oomah, B. D. 1998. Antioxidant activity and total phenolics in selected fruits, vegetable and grain products. Journal Agriculture Food Chemistry, 46: 4113-4117. 
تأثير المركبات الفينولية المستخلصة من ثمار التمر قبل النضج

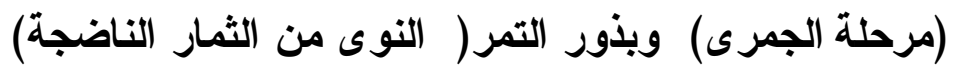

على أكسدة الدهون في سجق اللحم البقرى

\section{محمود فرحات سيد عواد قدوس}

قسم بحوث تكنولوجيا اللحوم والأسماك - معهل بحوث تكنولوجيا الأغنية - مركز البحوث الزراعية

قد أجريت هذه الدراسة لنقدير المحتوى الكلى للمركبات الفينولية و النثاط المضاد

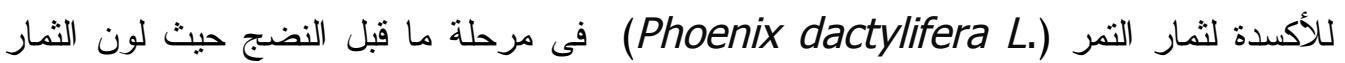

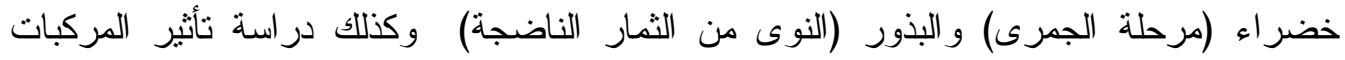

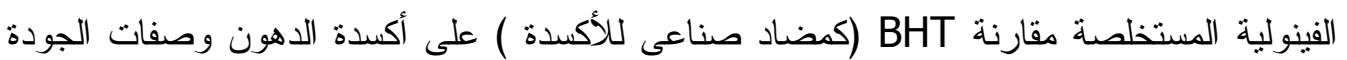

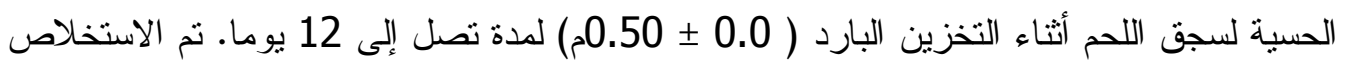

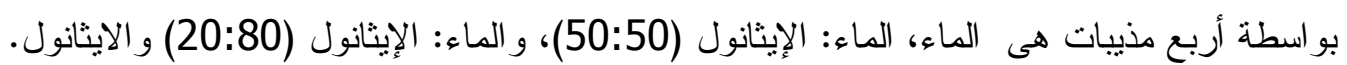

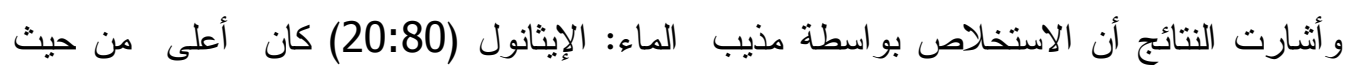

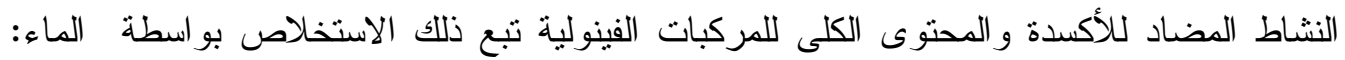

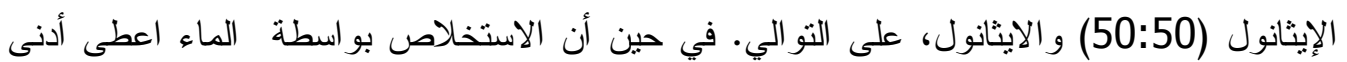

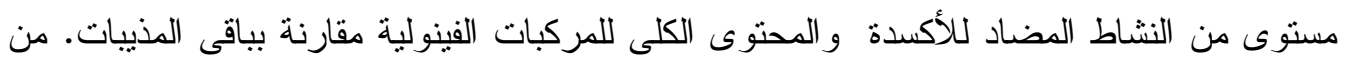

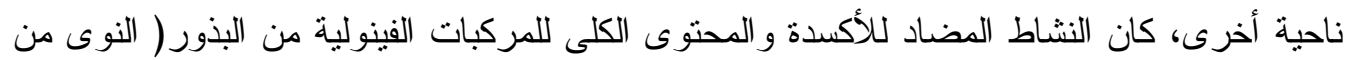

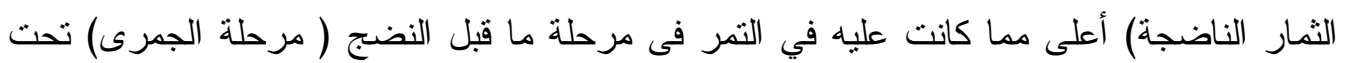

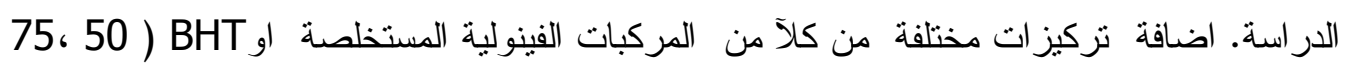

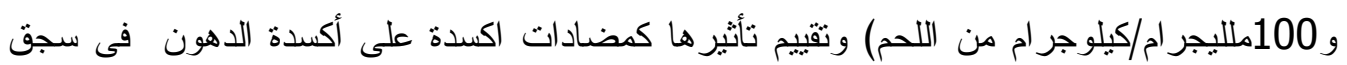

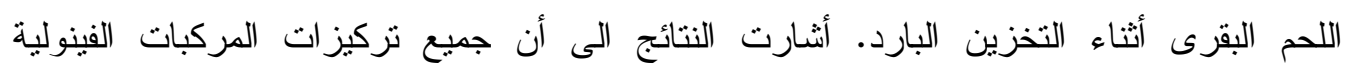

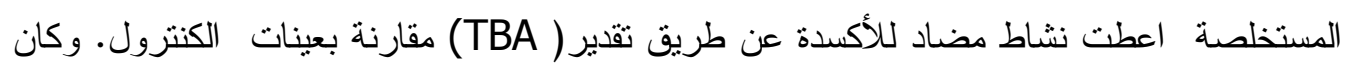

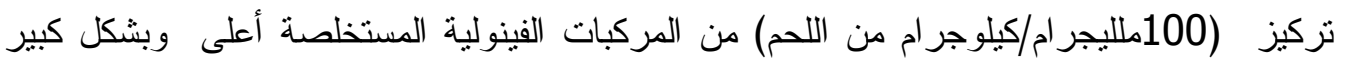

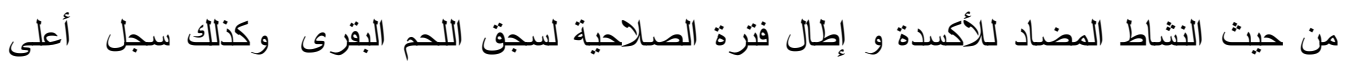
درجات النقيبم الحسي (اللون و الطعم والر ائحة و القو ام و القبول العام) خلال فترة التخزين و وعند نهاية

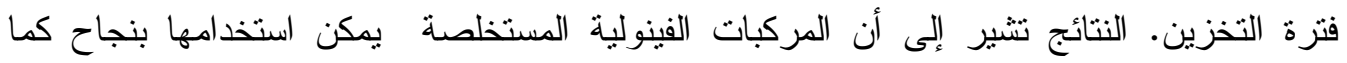

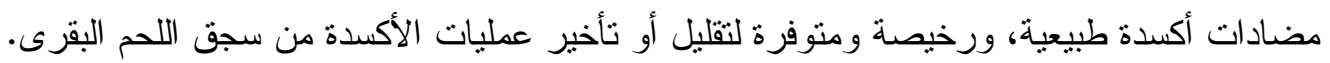

